\title{
Cancer among women of reproductive age in Nigeria
}

\author{
Uchendu Jude Obiora \\ Senior Lecturer, Department of Histopathology, Delta State University Teaching Hospital, Delta State, Nigeria
}

Background: Cancer in women of reproductive age is a poorly addressed but often preventable public health issue. Aims and Objectives: The study aims at analyzing cancer pattern among these women in the apex hospital in Delta State, Nigeria. Materials and Methods: The study is a 70-months descriptive retrospective study of histologically confirmed cases of cancer among women of 12-49 years (2014-2019). The corresponding age, organ and histologic diagnosis were examined and subsequently analyzed using excel spreadsheet 2007 . The result was presented in tables. Results: The author encountered 224 cancer cases among these women, representing $10 \%$ of all surgical specimens during the study period. The age range mean age of these women were $12-49$ and 39.09 years respectively. Breast, Colorectal, cervical, ovarian, skin, soft tissue and thyroid cancer accounted for 130 (58\%), $24(10.7 \%), 16(7.1 \%), 11(4.9 \%), 10(4.5 \%), 9(4 \%)$ and $7(3.1 \%)$ of the cases respectively. Those in the $2^{\text {nd }}, 3^{\text {rd }}$, fourth and fifth decades were $2(0.9 \%), 18,(8 \%), 96(42.7 \%)$ and $109(48.4 \%)$ cases respectively. Conclusion: Cancer is relatively common among women of reproductive age, but mostly affected the breast, colorectum, uterine cervix, ovary, skin, soft tissues and thyroid gland. There is need for all hands to be on deck to reverse the trend and improve the lives of those affected by the disease.

Key words: Women of reproductive age; Cancer; Diseases

\section{Access this article online}

Website:

http://nepjol.info/index.php/AJMS DOI: 10.3126/ajms.v11i3.26609

E-ISSN: 2091-0576

P-ISSN: 2467-9100

Copyright (c) 2020 Asian Journal of Medical Sciences

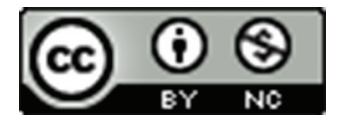

This work is licensed under a Creative Commons Attribution-NonCommercial 4.0 International License.

\section{INTRODUCTION}

Cancer in humans is ubiquitous and can develop in virtually any part of the body. ${ }^{1}$ Global statistics in 2018 showed that there were about 18.1 million new cancer cases and 9.6 million cancer deaths (equivalent to 26,000 cancer deaths per day). Cancer incidence among women has also been shown to vary substantially across various countries and within individual countries. Notably the leading cause of cancer among women worldwide is breast cancer, followed successively by colorectal, lung and cervical cancer. ${ }^{2}$

Apart from the associated high mortality and morbidity, cancer usually exerts serious emotional and economic burden to the family members of these victims. Traditionally, the young African women are responsible for child bearing and nurturing, feeding of family members and caring of the elderly populace. To some extent, she also contributes to the economic, educational and political development of the society. Consequently, the indirect cost of any debilitating illness, such as cancer, on these women to the society is enormous. ${ }^{3,4}$

Unfortunately, the present cancer rate among young women is expected to be on the rise in future because of present rate of smoking, obesity, physical inactivity, infections and changes in reproductive lifestyle (such as having first child at older age and reduced number of child births) among these women. ${ }^{5}$

The study therefore looks at the health status of these women with particular attention to cancer morbidity. In developed country, information concerning cancer is usually derived from high quality population-based cancer registry. ${ }^{6}$ Such structures are often absent in most low and middle income countries, leading to dependence on information from hospital data. Our analysis is therefore based on data from the apex hospital facility in this region. 
Prior to the period of this study, there was no previous study addressing this subject.

\section{MATERIALS AND METHODS}

This is a descriptive, retrospective study of cancer cases among women within the age of 12-49 years in DELSUTH during a 70 months period ( $1^{\text {st }}$ January 2014 to October $31^{\text {st }} 2019$ ).

All surgical specimens of these women with diagnosis of cancer were included in this study. Copies of histopathology report, request forms, corresponding tissue blocks and glass slides were analyzed and information such as corresponding age, organ involvement and histologic diagnosis were extracted.

These are subsequently analyzed using excel spread sheet 2007 and the results presented in tables.

\section{RESULTS}

Two hundred and twenty four cancer cases were encountered among women of reproductive age during the study period, accounting for $10 \%$ of all surgical specimens received in the department during the study period. The age range was 12-49 years and the mean age was 39.09 years respectively.

The organ site distribution of cancer among women of reproductive age is shown in Table 1. Breast. Colorectal, cervical, ovarian, skin, soft tissue and thyroid cancer accounted for 130 (58\%), 24(10.7\%), 16(7.1\%), 11(4.9\%), $10(4.5 \%), 9(4 \%)$ and $7(3.1 \%)$ of the cases respectively.

Age distribution of cancer in relation to organ sites of the cancer are shown in Table 2. Those in the $2^{\text {nd }}, 3^{\text {rd }}$, fourth and fifth decades were $2(0.9 \%), 18,(8 \%), 96(42.7 \%)$ and $109(48.4 \%)$ cases respectively.

\section{DISCUSSION}

To the best of our knowledge, this is the first study aiming to investigate cancer incidence among women of reproductive age in Delta State, Nigeria. These malignancies account for a good proportion of death among women of the age group, probably because most cases present as advanced disease. ${ }^{2}$ In Nigeria, little attention has been paid to non-communicable diseases (including cancers) among

\section{Table 1: Distribution of histologic types of cancer}

\begin{tabular}{|c|c|c|c|}
\hline Organ & Diagnosis & No of cases & Frequency \\
\hline Anus & SCC & 2 & 0.9 \\
\hline Bone & GCT & 2 & 0.9 \\
\hline \multirow[t]{5}{*}{ Breast } & IDC NST & 124 & 55.4 \\
\hline & Medullary Carcinoma & 2 & 1.0 \\
\hline & Metaplastic carcinoma & 1 & 0.5 \\
\hline & Mucinous carcinoma & 1 & 0.5 \\
\hline & Phylloides & 2 & 0.9 \\
\hline Cervix & Squamous cell carcinoma & 16 & 7.1 \\
\hline \multirow[t]{2}{*}{ Colon and Rectum } & Adenocarcinoma & 22 & 9.8 \\
\hline & Carcinoid tumour & 2 & 0.9 \\
\hline \multirow[t]{2}{*}{ Uterine Corpus } & Endometroid carcinoma & 1 & 0.5 \\
\hline & Leiomyosarcoma & 1 & 0.5 \\
\hline Hematolymphoid & Non-Hodgkins lymphoma & 2 & 0.9 \\
\hline \multirow[t]{5}{*}{ Ovary } & Yolk sac tumour & 2 & 0.9 \\
\hline & Granulosa cell tumour & 1 & 0.5 \\
\hline & Immature teratoma & 2 & 0.9 \\
\hline & Serous adenocarcinoma & 5 & 2.2 \\
\hline & Mucinous adenocarcinoma & 1 & 0.5 \\
\hline \multirow[t]{2}{*}{ Salivary gland tumor } & Adenoid cystic carcinoma & 1 & 0.5 \\
\hline & Basal cell adenocarcinoma & 2 & 0.9 \\
\hline \multirow[t]{3}{*}{ Skin } & Basal cell carcinoma & 1 & 0.5 \\
\hline & Kaposi sarcoma & 1 & 0.5 \\
\hline & Squamous cell carcinoma & 8 & 3.6 \\
\hline \multirow[t]{4}{*}{ Soft tissue } & Liposarcoma & 4 & 1.9 \\
\hline & Epitheloid sarcoma & 1 & 0.5 \\
\hline & Fibrosarcoma & 3 & 1.2 \\
\hline & Dermatofibrosarcomaprotuberance & 1 & 0.5 \\
\hline Stomach & Adenocarcinoma & 2 & 0.9 \\
\hline \multirow[t]{2}{*}{ Thyroid } & Medullary carcinoma & 2 & 0.9 \\
\hline & Papillary carcinoma & 7 & 3.1 \\
\hline Urinary bladder & Transitional cell carcinoma & 3 & 1.2 \\
\hline Vagina & Squamous cell carcinoma & 1 & 0.5 \\
\hline Total & & 224 & 100 \\
\hline
\end{tabular}




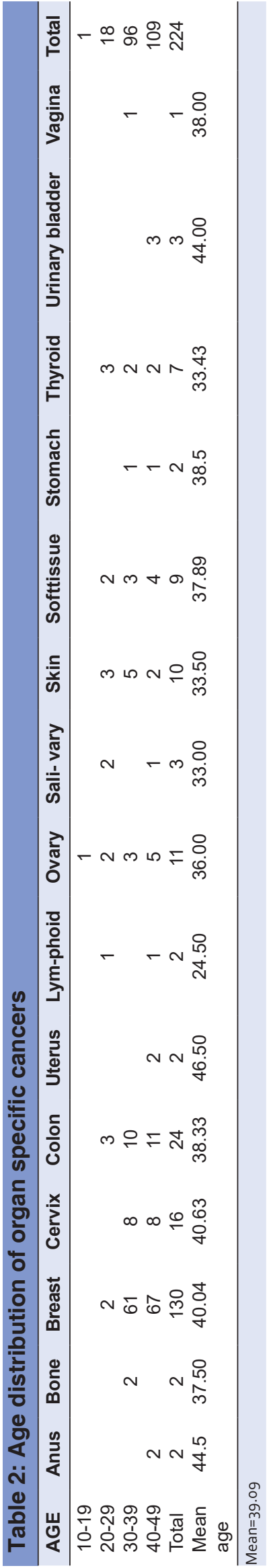

these women, who are also burdened with high morbidity and mortality arising from child bearing and pregnancy. ${ }^{7}$ It is therefore important to understand its trend, create the desired awareness and guide policy makers in effectively managing scarce resources.

The leading cancers in this study were encountered in the breast, colon, cervix, ovary, soft tissue, skin and thyroid gland. Put together, these amounted to $92.4 \%$ of all cancers among these women. Conspicuously, no single case of lung cancer was encountered in this analysis. Global report on cancer incidence however showed that lung cancer is the $3^{\text {rd }}$ most common cancer among female, accounting for $8.4 \%$ of cancers, although West African region had the lowest rate of lung cancer in that report. ${ }^{2}$ A study in a referral oncology center in Nigeria also noted the lung cancer is uncommon among Nigerian females. ${ }^{8}$ A combination of relatively low prevalence of cigarette smoking, unavailability of diagnostic facilities, and some possibly unidentified genetic protective factor may be responsible for the low incidence., ${ }^{2,9}$

Breast cancer is the most common cancer in this study. This is similar to reports of study across the globe, where it was shown to account for $24.2 \%$ of all cancer among women. ${ }^{2}$ Local studies also showed that it is the most common cancer among Nigerian women., ${ }^{2,810}$ Breast is an exposed organ and therefore lesions of the breast can be easily noticed and biopsied, and this may account for the relatively high rate of diagnosed breast cancer cases. ${ }^{11}$ The changing reproductive pattern characteristic of economic transition may support an increase in rate with time. ${ }^{2}$ Most cases in this study occurred in the $4^{\text {th }}$ and $5^{\text {th }}$ decade, with the mean age corresponding to 40.0 years. Sadly, earlier studies have demonstrated high mortality rate among young women with breast cancer, probably attributed to late presentation of affected patients. ${ }^{12,13}$ Nggada et al. suggested that massive public enlightenment, screening of at-risk population, early detection and proper management are indispensable in reducing the number of breast cancer cases and associated mortality in our region. ${ }^{14}$

Colorectal cancer is the $2^{\text {nd }}$ leading cancer in this report. Our report correlates well with estimated global rate, with colorectal cancer accounting for $9.4 \%$ of all cancer among females, while occupying the $2^{\text {nd }}$ position among the highest causes of cancer among women. ${ }^{2}$ With the prevailing risk factors such as obesity, physical inactivity, smoking; absence of population-based colorectal cancer screening programme, and nutritional transition, it is most likely that the rate of colorectal cancer will be on the rise in the future in this part of the globe. With urbanization, the traditional foods are gradually being replaced by high-energy snack foods, soft drinks, alcoholic beverages and food of 
predominantly animal source. The clinical outcome is also negatively affected by lack of government support and policy framework on cancer control, high cost of cancer treatment and unavailability of radiotherapy centers. ${ }^{2,15,16}$

Cervical cancer appeared relatively common in this study. Globally, it accounted for $6.6 \%$ of cancers among females, ranked fourth across all countries studied and second among developing countries. ${ }^{2}$ In that study, the highest incidence of cervical cancer was also observed among African population. ${ }^{2}$ Earlier studies have shown consistent association between cervical cancer and infection with sexually transmissible oncogenic strains of Human papillomavirus (HPV). Other identified risk factors include immunosuppression (as in Acquired Immunodeficiency Syndrome $\{$ AIDS $\}$ ), use of combined oral contraceptive pills and high parity. ${ }^{17}$ Cervical cancer has been shown to follow a slow course in its development, allowing for its detection and management at the pre-malignant phase. Lower rate of cervical cancer in developed countries may be attributed to the success of pap screening, and HPV vaccination. ${ }^{2}$ On the contrary, high prevalence of HPV infection, absence of organized population-based public health infrastructure for cervical cancer screening, and poor utilization of pap screening services are the major explanations to the relatively high rate of cervical cancer in this region. ${ }^{18}$

All cervical cancer cases encountered in this analysis were squamous cell carcinomas. The predominance of squamous cell cancer over other histological variants of cervical cancer is a global phenomenon. ${ }^{19}$

Skin cancers accounted for $4.5 \%$ of cancers cases in this study, with the affected patients having a mean age of 33.50 years. Incidence of skin cancer is generally relatively lower among blacks than the Caucasians because of protective effect of melanin pigment over skin cancer. ${ }^{2}$ Like in other African studies, our study showed that squamous cell carcinoma is the most common cutaneous malignancy among females. ${ }^{20}$ Ngbea and co-researchers, in North Central Nigeria, however reported a higher rate of Kaposi sarcoma among young women with skin cancer, probably because most of the patients recruited into that study were also suffering from AIDS. ${ }^{21}$

Ovarian cancer were also common in this study, consisting of six cases of epithelial and four cases of germ cell tumours. A study elsewhere however showed that ovarian cancer is the second most common malignancy among Nigerian women, ${ }^{22}$ a difference that may have been attributed to difference in the age range of women studied. Studies in Ibadan and Lagos showed that about $60 \%$ of patients with ovarian tumours were below the age of 50 years. ${ }^{23} \mathrm{~A}$ review of pattern of cancer in Ibadan cancer registry showed that ovarian cancer was the $3^{\text {rd }}$ most common cancer after breast and cervical cancer for women who were below the age of 45 years. $^{24}$

Thyroid cancer was the $7^{\text {th }}$ most common cancer observed in this study. Globally it is the $5^{\text {th }}$ most common cancers among females, accounting for $5.1 \%$ of the cases. ${ }^{2}$ In the general population, thyroid malignancies tend to be comparatively more common among the female gender. ${ }^{25,26}$ In this study, we noticed predominance of papillary cancer which agrees with reports from Amin in Abuja ${ }^{26}$ and Thomas and Ogumbiyi in Ibadan. ${ }^{27}$ Our report however contrast with report from Edino et al. in $\mathrm{Kano}^{28}$ and Abdukarim et al. in Lagos, ${ }^{29}$ showing predominance of follicular carcinoma.

In sum, we observed that cancer is relatively common among women of reproductive age, but mostly concentrated in a few organ sites. Possible specific preventive strategies include self-examination and mammography for breast cancer, fecal occult blood testing and sigmoidoscopy/ colonoscopy for colorectal cancer, pap test, visual inspection using lugol's iodine and deoxyribonucleic acid (DNA) testing for HPV for cervical cancer. Public enlightenment on signs and symptoms associated with these cancers will impact positively on the time of presentation while universal health coverage and health insurance will improve the quality of care of affected patients. There is need for government, public and individual participation towards reducing the menace of cancer among young women.

\section{ACKNOWLEDGEMENT}

The author is grateful to staff of Pathology department of Delta State University Teaching Hospital Oghara for their support during the project.

\section{REFERENCE}

1. Kumar V, Abbas AK and Aster CJ. Neoplasia. In: Kumar V, Abbas AK, Aster CJ (ed.).Robbins and Cotran Pathologic Basis of Disease. Philadelia, US: Elsevier \&Saunders; 2015, p.275.

2. Bray F, Ferlay J, Soerjomataram I, Siegel RL, Torre LA and Jemal A. Global Cancer statistics 2018: GLOBOCAN estimates of incidence and mortality worldwide for 36 cancers in 185 countries. CA Cancer J Clin 2018; 68(6):394-424. https://doi.org/10.3322/caac.21492

3. Ekwueme DU, Troggdon JG, Khavjou OA and Guy GP. Productivity Costs Associated With Breast Cancer Among Survivors Aged 1844 Years. Am J Prev Med 2016; 50(2):286-294.

https://doi.org/10.1016/j.amepre.2015.10.006

4. Bello G. Conditions of Women in Nigeria: issues and Challenges. Arts Social Sci J 2017; 8:293.

5. Kanavos $\mathrm{P}$. The rising burden of cancer in the developing world. 
Ann Oncol 2006; 17(8): 15-23.

https://doi.org/10.1093/annonc/mdl983

6. Das A: Cancer registry databases: an overview of techniques of statistical analysis and impact on cancer epidemiology. Methods Mol Biol 2009; 471: 31-49.

https://doi.org/10.1007/978-1-59745-416-2_2

7. United Nations (UN), World health organization (WHO) and World Bank partner to combat maternal mortality. The World Bank group news release no.2000/080/S.

8. Sowunmi A, Alabi A, Fatiregun O, Olatunji T, Okoro US and Durosinmi Etti AF. Trend of cancer incidence in an oncology center in Nigeria. West Afr J Radiol 2018; 25: 52-56.

https://doi.org/10.4103/wajr.wajr_26_17

9. Urman A, Josyula S, Rosenberg A, Lounsbury D, Rohan T, et al. Burden of Lung Cancer and Associated Risk Factors in Africa by Region. J Pulm Respir Med 2016; 6:340. https://doi.org/10.4172/2161-105X.1000340

10. Ihezue $C$, Ugwu B and Nwana E. Breast Cancer in Highlanders. Nigerian J Surg Sci 1994; 4: 1-4.

11. Kumar V, Abbas AK and Aster JC. The breast. In: Kumar V, Abbas AK, Aster CJ (ed.).Robbins and Cotran Pathologic Basis of Disease. Philadelia, US: Elsevier \& Saunders; 201, p.1043-1071.

12. Ohanaka CE. Breast Cancer in Young Nigerian Women. Niger J Surg Sci 2007; 17 (2): 86-90. https://doi.org/10.4314/njssci.v17i2.38410

13. Ntekim A, Nufu FT and Campbell OB. Breast cancer in young women in Ibadan, Nigeria. Afr Health Sci 2009; 9(4): 242-246.

14. Nggada HA1, Yawe KD, Abdulazeez $J$ and Khalil MA. Breast cancer burden in Maiduguri, North eastern Nigeria. Breast $\mathrm{J}$ 2008; 14(3):284-286. https://doi.org/10.1111/j.1524-4741.2008.00576.x

15. Irabor DO. Emergence of colorectal cancer in West Africa: Accepting the inevitable. Niger Med J 2017; 58:87-91.

16. Giovannucci E1. Modifiable risk factors for colon cancer. Gastroenterol Clin North Am 2002; 31(4):925-943. https://doi.org/10.1016/S0889-8553(02)00057-2

17. IARC Working Group on the Evaluation of Carcinogenic Risks to Humans. Human papilloma viruses. IARC Monogr Eval Carcinog Risks Hum 2007;90:1-636.
18. Ogu RN and Ojule JD. Overview and Prevention of Cervical Cancer. TNHJ 2014; 14(4):143-149.

19. Sule $A A$ and Ochicha $O$. A histopathologic review of cervical cancer in Kano, Nigeria. SMJ 2017; 20(1):16-20.

20. Ochicha O, Edino ST, Mohammed ST and Umar AB. Dermatological malignancies in Kano, Northern Nigeria: a histopathological review. Ann Afr Med 2004; 3(4):188-219. https://doi.org/10.4314/wajm.v22i3.27949

21. Ngbea JA, Vhriterhire AR, Akpor IO, Terhemba N, Ugbaje BA, Ojo BA, et al. Histopathological review of dermatological malignancies in Makurdi, North Central Nigeria. Ann Trop Pathol 2018; 9:75-78. https://doi.org/10.4103/atp.atp_12_18

22. Zayyan MS, Ahmed SA, Oguntayo AO, Kolawole AO and Olasinde TA. Epidemiology of ovarian cancers in Zaria, Northern Nigeria: a 10-year study. Int J Womens Health 2017; 9: 855-860. https://doi.org/10.2147/IJWH.S130340

23. Okunade KS, Okunola H, Okunowo AA and Anorlu RI. A five year review of ovarian cancer at a tertiary institution in Lagos, South-West, Nigeria. Niger J Gen Pract 2016;14:23-27. https://doi.org/10.4103/1118-4647.187901

24. Jedy-Agba E, Curado MP, Ogunbiyi O, Oga E, Fabowale T, Igbinoba F, et al. Cancer Incidence in Nigeria: A Report from Population-based Cancer Registries. Cancer Epidemiol 2012; 36(5): 271-278.

https://doi.org/10.1016/j.canep.2012.04.007

25. Maitra A. The endocrine system. In: Kumar V, Abbas AK, Aster CJ (ed.). Robbins and Cotran Pathologic Basis of Disease. Philadelia, US: Elsevier \&Saunders; 2015; p.1094

26. Amin SM, Jawa ZM, Gowon JP, George OF, Gagarawa YA and Eiyeje OI. A 10-year review of thyroid lesions in a tertiary hospital in Abuja, Nigeria. Ann Trop Pathol 2018; 9:118-120. https://doi.org/10.4103/atp.atp_21_18

27. Thomas JO and Ogunbiyi JO. Thyroid cancers in Ibadan, Nigeria. East Afr Med J 1995; 72:231-238.

28. Edino ST, Mohammed AZ and Ochicha O. Thyroid diseases in Kano. Niger Postgrad Med J 2004; 11:103-106. https://doi.org/10.4314/nqjhm.v11i1.12494

29. Abdulkareem FB, Banjo AA and Elesha SO. Histological review of thyroid lesions: A 13-year retrospective study (1989-2001). Niger Postgrad Med J 2005; 12:210-214.

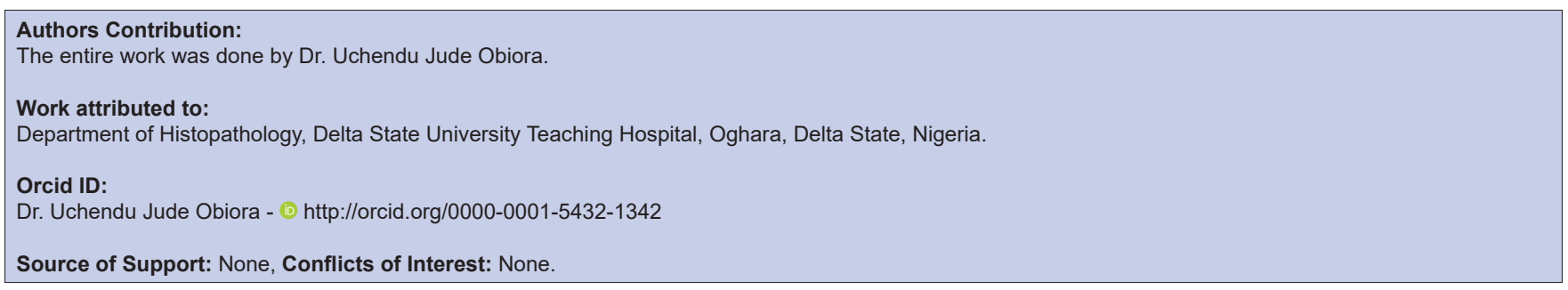

